DOI: 10.34015/2523-4552.2019.1.15

УДК 343.81

Халавка В. I., начальник Софіївської виправної колонії № 45 Міністерства юстиції України

\title{
ПІДВИЩЕННЯ ЯКОСТІ ЗАСТОСУВАННЯ ЗАОХОЧУВАЛЬНИХ ТА ЗАБОРОННИХ ЗАХОДІВ У ДЕРЖАВНИХ І ПРИВАТНИХ КРИМІНАЛЬНО-ВИКОНАВЧИХ УСТАНОВАХ
}

У статті аналізується застосування заохочувальних та заборонних заходів персоналом кримінально-виконавчої служби. Розглянуто, як засвоюються вказані заходи засудженими до позбавлення волі. Визначено проблеми неякісного карально-виправного впливу на засуджених до позбавлення волі працівників установ, основними серед яких $\epsilon$ недостатність або відсутність відповідних професійних навичок, брак часу, що не дає можливості якісно застосовувати індивідуальні та диференційовані заходи впливу, відсутність належного фінансування.

Висвітлено питання запровадження досвіду іноземних країн у застосуванні заохочувальних та заборонних заходів у державних і приватних кримінально-виконавчих установах виконання покарань.

Ключові слова: заохочувальні заходи; заборонні заходи, засуджені, реалізація покарання, кримінально-виконавча служба, персонал.

В статье анализируется применение поощрительных и запрещающих мер персоналом уголовно-исполнительной службы. Рассмотрено, как осужденными к лишению свободы усваиваются указанные меры. Определены проблемы некачественного карательно-исправительного воздействия на осужденных к лишению свободы работников учреждений, основными из которых являются недостаток или отсутствие соответствующих профессиональных навыков, дефицит времени, не дающий возможности качественно применять индивидуальные и дифференцированные меры воздействия, отсутствие надлежащего финансирования.

Освещены вопросы внедрения опыта зарубежных стран по применению поощрительных и запрещающих мер в государственных и частных уголовноисполнительных учреждениях исполнения наказаний.

Ключевые слова: поощрительные меры; запрещающие меры; осужденные; реализация наказания; уголовно-исполнительная служба; персонал.

Постановка проблеми. Проблеми зміцнення правопорядку в суспільстві, протидії злочинності були і залишаються одними з найважливіших, а тому не випадково, що за всю свою історію розвитку людство намагалося будь-яким способом боротися проти проявів, які суперечили загальноприйнятим поняттям моралі, громадської безпеки та по- 
рядку. Забезпечувати дотримання вимог Конституції України, інших законів - це обов'язок усіх органів держави і посадових осіб, громадських організацій і громадян [1, с. 4]. Визначивши це, наша держава приєдналася до європейського і світового бачення зазначеної проблеми, намагається створити відповідні передумови для їі вирішення в усіх сферах взаємин особи і суспільства, громадянина і держави.

Поступове втілення політики лібералізації українського суспільства вплинуло на суттєву перебудову кримінально-виконавчого законодавства й відомчих нормативних актів, що, зокрема, позначилося на створенні нової правової бази, спрямованої на захист прав засуджених, у тому числі у сфері застосування заохочувальних та заборонних заходів. Однак аналіз проблем практики й теоретичних поглядів на застосування вказаної правової бази свідчить, що вона має свої специфічні особливості, пов'язані із суттєвим впливом положень відомчих актів на реалізацію покарання, особливо засудженням до позбавлення волі. Тому доцільним є аналіз норм вітчизняного кримінально-виконавчого права та інших нормативноправових актів, діяльності персоналу, який регулює, забезпечує та виконує заохочувальні та заборонні заходи, з метою вдосконалення українського законодавства.

Крім зазначеного, необхідно підкреслити, що професійна діяльність персоналу кримінальновиконавчої служби (далі - КВС) базується на реалізації правових і моральних вимог, а дотримання законності та недопущення ними правопорушень - головний показник зрілості та надійності працівників. У зв'язку із цим суттєвого значення набувають питання,наскільки персонал КВС $€$ професійним, здатним виконувати поставлені завдання. Адже поряд 3 удосконаленням структури, технічною модернізацією кримінальновиконавчих установ (далі - КВУ) необхідно концентрувати увагу на підвищенні якісного рівня кадрів, розвитку нових форм застосування карально-виховних заходів до засуджених, які відбувають покарання, i управління цим процесом, удосконаленні системи стимулювання й оцінки поведінки засуджених, ініціюванні їх самовдосконалення та виправлення. Проте, ураховуючи специфіку роботи установ та їх закритість, частина питань залишаються невирішеними.

Треба вказати й те, що існуюча кримінально-виконавча система має суттєві недоліки в частині фінансового забезпечення, що впливає на дотримання засудженими режимних вимог, не дає повною мірою застосовувати заходи, що визначені карально-виправним впливом. Через брак коштів у державі дедалі частіше обговорюється питання створення приватних в'язниць, оскільки ця модель існує в багатьох країнах світу.

Усе зазначене підкреслює актуальність питання застосування заохочувальних та заборонних заходів персоналом кримінально-виконавчої служби.

Аналіз останніх досліджень і публікацій. На теренах незалежної України над проблемами кримінально-виконавчого права досить плідно працюють такі науковці, як К. А. Автухов, В. А. Бадира, І. Г. Богатирьов, I. В. Боднар, А. В. Градецький, С. Ф. Денисов, Т. А. Денисова, О. М. Джужа, 
В. М. Дрьомін, О. Г. Колб, І. М. Копотун, О. Г. Крикушенко, О. В. Лисодєд, В. М. Пальченкова, М. С. Пузирьов, Г. О. Радов, А. Х. Степанюк, В. М. Трубников, С. В. Царюк, Ю. В. Шинкарьов, I. С. Яковець та ін. Однак, незважаючи на значну кількість наукових праць, зазначені питання залишаються дискусійними та не мають чіткого визначення. Передусім, це стосується можливостей здійснення комплексного, якісного каральновиправного впливу на засуджених.

Постановка завдання. Дослідити застосування заохочувальних та заборонних заходів персоналом КВC, визначити прогалини та недоліки цієї роботи та показати досвід іноземних країн у застосуванні заохочувальних та заборонних заходів у державних та приватних кримінально-виконавчих установах виконання покарань.

Виклад основного матеріалу. Частиною першою статті 1 Кримінально-виконавчого кодексу України (далі - КВК) визначено, що кримінально-виконавче законодавство регламентує порядок і умови виконання та відбування кримінальних покарань 3 метою забезпечення досягнення цілей покарання, а саме кари, виправлення і ресоціалізації засуджених, запобігання вчиненню нових злочинів як засудженими, так i іншими особами [2]. Основне навантаження з реалізації покарання лягає на кримінально-виконавче законодавство та діяльність адміністрацій КВУ. Не менш серйозним завданням $\epsilon$ створення належних умов для виправлення і ресоціалізації засуджених, а також мінімізація несприятливого впливу покарання на особу засудженого і звільненого. I дуже важливим, на наш погляд, є декларуван- ня державою шляхів вирішення цих завдань, зокрема, визначення основних організаційних і правових принципів надання соціальних послуг особам, що знаходяться в складних життєвих обставинах після звільнення з місць позбавлення волі.

Виходячи із сутності та змісту покарання, його заборонні заходи реалізуються шляхом установлення різних правообмежень засудженим у процесі відбування покарання. Вони охоплюють, насамперед, сферу їх суб'єктивних прав. Одне кримінальне покарання відрізняється від іншого (наприклад, позбавлення волі від громадських робіт), насамперед, змістом карального впливу, тим, які права та законні інтереси і якою мірою зачіпаються при виконанні покарання, які страждання та труднощі відчуває при цьому засуджений.

У науковій літературі та більшості нормативних документів Міністерства юстиції України на заборонні та заохочувальні засоби покладається забезпечення режиму i заходів впливу на засудженого, що сприяє досягненню цілей покарання на стадії його виконання і відбування, тому що цей процес $\epsilon$ цілісним $\mathrm{i}$ єдиним. Заборонні заходи здійснюються в процесі діяльності УВП і $\epsilon$ практичним вираженням теоретичних положень кримінальновиконавчого права, системи поглядів, концепцій, теорій про застосування покарання. Зокрема, у разі позбавлення волі особи заборонні заходи включають фізичну ізоляцію засуджених від суспільства, що полягає в забезпеченні охорони території, де вони перебувають, необхідності пересування під конвоєм тощо. Не допускається спілкування засуджених поза встановленими правилами 
з особами, які знаходяться на волі. Їм заборонено порушувати межі житлових і виробничих об'єктів, виходити без дозволу адміністрації за межі ізольованих ділянок. Хоча фізична ізоляція засуджених має відносний характер, на перший погляд, зберігається їх духовна свобода. Проте насправді перебування в ізоляції назавжди залишає на позбавлених волі особах негативні відбитки - фізичні, духовні, матеріальні. Особливо такі негативні прояви спостерігаються в жінок та неповнолітніх, оскільки викликають у засуджених образу, невдоволення і навіть відчай, адже через особливий правовий статус засуджених обмежуються їх матеріальні та духовні потреби. Так, пересування територією та вільний час суворо регламентуються, їжа видається в певний час і за визначеними нормами, обмежено задоволення статевих потреб. Також засуджені обмежені в можливості виявляти безпосередню турботу про сім'ю, виховувати дітей, спілкуватися з батьками та рідними тощо. Соціальна ізоляція пригнічує особу і навіть може викликати психічні стреси.

Шляхом заохочення до правослухняної поведінки засудженим надається право на побачення і телефонні переговори, короткострокові виїзди за межі місць позбавлення волі, вони мають змогу листуватися. Ступінь ізоляції істотно знижується у зв'язку з використанням засудженими засобів масової комунікації, що забезпечує постійний духовний вплив суспільства на осіб 3 метою повернення їх до суспільно корисної праці. Особливе місце в системі заходів заохочення займає умовнодострокове звільнення осіб, які відбувають покарання у виді позбав- лення волі, що є одним із найбільш поширених видів звільнення від відбування покарання та успішно застосовується як в Україні, так і в більшості країн світу.

Таким чином, неухильне дотримання правил режиму є основою для виконання і відбування кримінального покарання, ефективного використання інших засобів виправлення засуджених. До того ж режим відповідно до частини третьої статті 6 КВК $є$ одним 3 основних засобів виправлення і ресоціалізації засуджених, який застосовується $з$ урахуванням виду покарання, тяжкості й мотивів учиненого злочину, особи винного [2]. У літературі наведено різні визначення поняття режиму, але зазвичай під режимом розуміють сукупність норм кримінальновиконавчого права, які регулюють порядок і умови виконання та відбування кримінальних покарань, що забезпечують реалізацію кари стосовно засуджених, і умови, що створюють 3 метою ефективного застосування інших заходів виховного впливу.

Незважаючи на важливість означеного, постає питання про те, чому застосування заохочувальних та заборонних заходів у процесі здійснення карально-виправного впливу нерідко не приводить до бажаного результату - виправлення та ресоціалізації засуджених. Як видається, відповідь на це питання має дві складові частини.

По-перше, це персонал, його професіоналізм, спроможність комплексно і якісно впливати за засуджених, стимулювати до правослухняної поведінки та засвоєння виправних програм [3, с. 296-298]. Підкреслимо, що до суб'єктів, які здійсню- 
ють карально-виправний вплив на засуджених, треба відносити керівництво на чолі з начальником, заступників начальника УВП (за нагляду і безпеки, з організації охорони, із соціально-виховної роботи);керівників відділів і служб, окремих посадових осіб. Зокрема, це начальник і працівники оперативного відділу; начальник і працівники відділу з нагляду і безпеки; начальник i працівники відділу з організації охорони; черговий помічник начальника УВП з підлеглими; начальник відділення соціально-психологічної служби, начальник відділу з контролю за виконанням судових рішень, інспектори та психологи. Крім того, працівники виробничо-технічних служб, матеріально-побутового забезпечення, представники загальноосвітнього i професійно-технічного навчання, медичної служби УВП на чолі з керівниками вказаних відділів та служб, а також інший особовий склад, який,у межах компетенції, залучається до впровадження заохочувальних та заборонних заходів.

По-друге, це категорія засуджених, які відбувають покарання. 3 цього приводу А. Х. Степанюк зауважує,що свідомість засудженої особи підлягає примусовому коригуванню, результатом якого має бути виправлення та ресоціалізація. Однак, торкаючись процесу виправлення особи, він зазначає, що примусове виправлення не здатне привести до очікуваних результатів, бо воно зустрічає якщо не опір, то щонайменше неприйняття його з боку засуджених [4, с. 4-13]. Можливо, через звикання до певного протоколу поведінки i справді можна вплинути на звички особи, однак абсолютно не доведено те, що це пов'язано зі зміною свідомо- сті людини в позитивний бік. Найчастіше ці звички не впливають на механізми мотивації та прийняття рішень під впливом пріоритету соціальних норм, якщо, звичайно ж, особа добровільно не переосмислила своє життя і ціннісні орієнтації, а головне, не схиляється до виправдовування досягнення власних цілей через можливість знехтувати інтересами інших. Крім того, якщо персоналом заохочувальні або заборонні заходи, виправні програми тощо будуть застосовуватися недостатньо або неправильно, то засуджений буде всіляко протистояти виховному процесу, навіть якщо загалом його поведінка є правослухняною. Тому важливо дотримувати рівновагу між тиском (обов'язковим виконанням усіх режимних розпоряджень, інших заборонних заходів) і підтримкою (запобіганням емоційно-афективному перенапруженню, стабілізацією внутрішнього стану, переключенням видів діяльності, залученням громадськості), щоб у процесі відбування покарання стимулювати засудженого до виправлення.

Розгляд можливостей УВП якісно впроваджувати заходи каральновиправного впливу дає підстави стверджувати про недосяжність позитивного результату в умовах недостатньої кваліфікації персоналу за цим напрямом та у зв'язку з обмеженим фінансуванням установ. Альтернативою УВП державного зразка могли би стати приватні кримінальновиконавчі установи (далі - ПКВУ), дискусія про можливість упровадження яких у систему виконання покарань триває не один рік. На нарадах, що проводяться Міністерством юстиції України, на наукових конференціях, у непоодиноких пуб- 
лікаціях та висловлюваннях правників і правозахисників існує низка діаметрально протилежних думок щодо цього питання, наводиться як позитивний, так і негативний досвід інших країн.

Нами також проаналізовано досвід Великобританії, Ізраїлю, Казахстану, США та ін. щодо можливості функціонування ПКВУ. Зокрема, 3 початку 2000-х років в Ізраїлі та Казахстані 3 ентузіазмом сприйнято впровадження приватних в'язниць як альтернативи державним УВП, взірцем упровадження європейських стандартів. Проте реальністю ПКВУ так і не стали. Так, в Ізраїлі закон, що допускав існування приватних в'язниць, схвалений парламентом у 2004 р., а компанія AFI Group навіть побудувала будинок на 2000 осіб. Але в'язницю так і відкрито, оскільки у 2009 р. Верховний суд Ізраїлю визнав цей закон таким, що суперечить Конституції країни. У поясненні сказано, що одним з базових правових принципів в Ізраїлі $\epsilon$ те, що право на використання насильства, зокрема, на дотримання кримінально-виконавчого законодавства шляхом поміщення людей за грати $є$ одним 3 основних повноважень держави. Передача права утримувати людей в'язницям, які є приватними компаніями та мають на меті одержання прибутку, позбавляє вирок легітимності. Так само Міністерство національної економіки Республіки Казахстан дало негативний економічний висновок за проектом «Будівництво і здача в експлуатацію виправної установи на 1500 місць в Південно-Казахстанській області (м. Шимкент)». Незважаючи на те, що ця в'язниця повинна була відповідати євростандарту, що включає в себе медичний блок, школу, культурно- спортивний блок з магазином, бібліотеку, перукарню й актовий зал, у їі будівництві відмовлено, а кошти передано на будівництво державної виправної колонії.

Крім указаних, можна навести й інші приклади (Молдова, Російська Федерація тощо), коли причинами відмовив побудові та використанні ПКВУ були численні протести правозахисників, які наполягали, що приватні в'язниці за своєю сутністю $€$ узаконеним рабством, оскільки державні виправні установи - це місце відбування покарання та виправлення людини, а приватні - просто бізнес на людях, використання трудових ресурсів для отримання прибутку. Виправлення засудженого і його подальша ресоціалізація власників ПКВУ не турбують. На жаль, більшість висловлювань «проти» стосувалася лише використання праці засуджених.

Існує позитивний досвід функціонування ПКВУ, зокрема, у Великобританії, Голландії, Німеччині, США, особливо в частині використання можливостей карально-виправного впливу на засуджених. Так, у США для проведення виправних програм, що включають заохочувальні та заборонні заходи, за кошти приватної установи за тимчасовою трудовою угодою проводиться набір професіоналів, які застосовують свої знання, навички, досвід для виправлення засуджених. У Великобританії $\epsilon$ i приватні, i державні в'язниці, при цьому практично відсутні будь-які порушення та зловживання персоналу. Навпаки, утримання одного ув'язненого в приватній в'язниці дешевше, ніж у державній, їжа більш калорійна, умови утримання значно кращі. На конкурсній основі прово- 
диться відбір персоналу, основним завданням якого $є$ виправлення та ресоціалізація засудженого.

Про можливості запровадження ПКВУ досить влучно висловився заступник Міністра юстиції Д. В. Чернишов, який підкреслив, що «ця модель існує в багатьох країнах світу. Наприклад, у США держава платить таким бізнесменам гроші з розрахунку витрат на одного ув'язненого. Вони перед цим виставляють свої пропозиції на конкурсі. А держава не витрачає коштів на будівництво. Природно, що в такому випадку існують законодавчі правила, які регламентують режим утримання ув'язнених у приватних закладах, зміст виправних заходів тощо» [5].

Нами здійснено інтерв'ювання персоналу, правозахисників, пересічних громадян та засуджених з приводу можливостей побудови та функціонування приватних установ в Україні. На жаль, більшість пересічних громадян та правозахисників негативно сприйняли таку ідею (обирати можна було декілька варіантів відповідей або дати власну). Свою думку вони обгрунтовували тим, що приватні особи будуть зловживати залученням засуджених до тяжкої праці (62%), мати надлишкові прибутки, з яких на утримання в'язниць передаватиметься мінімум коштів (21 \%),створювати комфортні умови для відбування покарань для засуджених окремих категорій (33 \%). Серед персоналу, який висловився проти приватних установ, домінувала думка про те, що не буде забезпечено професійну охорону та нагляд за засудженими (41 \%), не всі засуджені перебуватимуть у рівних умовах (31 \%).

Прихильниками впровадження ПКВУ здебільшого були засуджені та частина персоналу. Їх відповіді торкалися належного фінансового забезпечення (47\%), харчування (89 \%), належних умов утримання (24\%), працевикористання, що дасть змогу отримати гідну професію для майбутнього (42\%).

Необхідно підкреслити, що опитаними на карально-виправний вплив, який необхідно здійснювати в УВП, жодним чином не вказано. Це ще раз спонукає до думки, що сьогодні у виправних колоніях на виправні програми, заходи заборонні та, особливо, заохочувальні достатня увага не звертається.

Ми переконані, що суспільство повинно зробити певні висновки. Система виконання покарань України знаходиться на переломі, коли стали очевидними загострені розбіжності між консервативністю чинного кримінально-виконавчого законодавства і рухом країни до гуманізму та демократії, побудови правової держави. Кримінально-виконавча система останнім часом переживає складний період, бо виявилася заручницею змін, що відбуваються в Україні. Діяльність установ охоплює широкі верстви населення: від самих засуджених та адміністрації колоній до родичів, потерпілих і свідків. За останні роки місця позбавлення волі змінилися, нажаль, не на краще: відзначається високий рівень злісних правопорушень засуджених, що, у свою чергу, призводить до критичних ситуацій у деяких із них і значно ускладнює оперативну обстановку, бракує коштів на сучасне будівництво, медичне забезпечення тощо. Шкода, що в умовах сучасної моделі економіки держава втратила економічний інтерес до системи та загалом до людей, які відбувають пока- 
рання і працюють у ній. Ми переконані, що зміни в УВП повинні мати на меті як підвищення ефективності діяльності кримінально-виконавчої системи, дотримання прав осіб, стосовно яких виконується покарання, так і повернення суспільству громадян, які надалі відмовляться від учинення суспільно небезпечних діянь.

Висновки. Таким чином, кримінально-виконавчі заохочувальні та заборонні заходи повинні підпорядковуватися пенітенціарній ідеї та

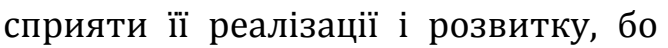
саме вона на грунті каяття за вчинений злочин акумулює в собі соціальну мету та потребу суспільства в досягненні стану виправлення й ресоціалізації злочинця, а на цьому грунті - становлення його як законослухняної людини.

Заохочувальні та заборонні заходи мають застосовуватися комплексно і всебічно як виховними так і оперативно-режимними засобами в процесі здійснення виправного впливу. За кожен захід повинен від- повідати персонал УВП,на якого покладено організацію і безпосереднє здійснення заходів. Класифікація таких суб'єктів дозволить визначити обсяг впливу на засуджених нарізних етапах відбування покарання, а також виключити можливість сплутування різних за змістом, спрямованістю і характером заходів. Необхідно підкреслити комплексність такої діяльності, що включає системність роботи, яка ведеться в межах УВП, комплексну взаємодію всіх частин і служб за цим напрямом та передбачає здійснення спільних планових і оперативних заходів, які реалізуються персоналом у встановлені строки.

Узагальнюючи досвід запровадження приватних установ виконання покарань, можна вказати, що в Україні такі можливості є. Акцент повинен бути не на підприємницькій діяльності, виснажливій праці засуджених, а на створенні умов для відбування покарання, виправленні та ресоціалізації засуджених.

\section{Список використаних джерел}

1. Конституція України: Прийнята на п'ятій сесії Верховної Ради України 28 червня 1996 р. Київ : Преса України, 1997. 80 с.

2. Кримінально-виконавчий кодекс України: Закон України від 11.07. 2003 p. № 1129-IV. Відомості Верховної Ради України, 2004, № 3-4, ст. 21. Редакція від 04.11.2018, підстава 2581-VIII. URL : https://zakon.rada.gov.ua/laws/show/1129-15 (дата звернення: 13.05.2018).

3. Денисова Т. А. Нотатки до ст. 391 КК України «Злісна непокора вимогам адміністрації установи виконання покарань. Кримінально-правове забезпечення сталого розвитку України в умовах глобалізації: матер. Міжнародної науково-практичної конференції, 12-13 жовтня 2017 р., Харків : ГО «Всеукраїнська асоціація кримінального права». С. 296-300.

4. Степанюк А.Х. Умови відбування покарання засудженими жінками. Acпект: Информационный бюлетень. 2005. № 1. С. 4-13.

5. Чернышов Д. В Минюсте рассказали о том, как работают частные тюрьмы. Espreso.tv. Новости. Общество. 19 июня, 2018. URL: https://ru.espreso.tv/news/ 2018/06/19/v (дата звернення: 13.05.2018). 


\section{References}

1. Konstituciya Ukrayini: Prijnyata na p'yatij sesiyi Verhovnoyi Radi Ukrayini 28 chervnya 1996 r. Kiyiv: Presa Ukrayini (1997) [in Ukrainian].

2. Kriminalno-vikonavchij kodeks Ukrayini: Zakon Ukrayini vid 11.07. 2003 r. № 1129-IV. Vidomosti Verhovnoyi Radi Ukrayini, 2004, № 3-4, st. 21. Redakciya vid 04.11.2018, pidstava 2581-VIII. URL : https://zakon.rada.gov.ua/laws/show/1129-15 (data zvernennya: 13.05.2018) [in Ukrainian].

3. Denisova, T. A. (2017). Notatki do st. 391 KK Ukrayini «Zlisna nepokora vimogam administraciyi ustanovi vikonannya pokaran, Kriminalno-pravove zabezpechennya stalogo rozvitku Ukrayini $v$ umovah globalizaciyi: mater. Mizhnarodnoyi naukovopraktichnoyi konferenciyi, 12-13 zhovtnya 2017 r. Harkiv: GO «Vseukrayinska asociaciya kriminalnogo prava» [in Ukrainian].

4. Stepanyuk, A. H. (2005). Umovi vidbuvannya pokarannya zasudzhenimi zhinkami. Aspekt: Informacionnyj byuleten. 1, 4-13 [in Ukrainian].

5. Chernyshov, D. V Minyuste rasskazali o tom, kak rabotayut chastnye tyurmy. Espreso.tv. Novosti. Obshestvo. 19 iyunya, 2018. URL: https://ru.espreso.tv/news/ 2018/06/19/v (data zvernennya: 13.05.2018) [in Russian].

V. Khalavka, Head of the Sophia Correctional Facility of the Ministry of Justice of Ukraine

\section{Improving the quality of incentive and prohibitive measures in public and private penitentiary institutions}

The article analyzes the use of incentive and prohibitive measures by staff of the penitentiary service. The main purpose of the article is to study the use of incentive and prohibitive measures by the staff, to identify gaps and weaknesses in this work. It also requires an analysis of the experience of foreign countries in the application of incentive and prohibitive measures in public and private penitentiary institutions for the execution of sentences.

The analysis of the norms of domestic criminal-executive law and other regulatory acts governing the provision of incentive and prohibitive measures in order to improve the Ukrainian legislation. Considered the role of staff. It was emphasized that the professional activity of the staff of the penitentiary service is based on the implementation of legal and moral requirements. Compliance with the law and the prevention of offenses is the main indicator of the maturity and reliability of reliability. The issues of assimilation of these measures by prisoners sentenced to imprisonment are considered. Problems of poor punitive-corrective impact on convicts. The main ones are: lack of or lack of relevant professional skills; lack of time that does not allow for the qualitative application of individual and differentiated interventions; lack of adequate funding.

Summarizing the experience of foreign countries, it is indicated that in Ukraine there are opportunities for the functioning of private institutions for the execution of sentences. It was noted that the focus should not be on business activities, but on creating conditions for serving the sentence, rectifying and re-socializing convicts. 
The findings indicate that incentive and prohibitive measures accumulate in themselves the social goal and the need of society for attaining the state of correction and re-socialization of the criminal and on this basis his becoming as a lawabiding person.

Incentive and prohibitive measures should be applied comprehensively and comprehensively as educational and operational-sensitive means in the implementation of corrective action. It is noted that the complex interaction of all parts and services in this direction and provides for the implementation of joint planned and operational activities that are implemented by staff in a timely manner for their implementation.

Keywords: incentive measures; prohibitive measures; convicts; the implementation of punishment; the penitentiary service; personnel.

Надійшла до редакції 13.05.2019 